\title{
TRANSPLANTATION OF ACTIVATED NUCLEUS PULPOSUS CELLS AFTER CRYOPRESERVATION: EFFICACY STUDY IN A CANINE DISC DEGENERATION MODEL
}

\author{
T. Nukaga ${ }^{1,2}$, D. Sakai ${ }^{1,2}$, M. Tanaka ${ }^{1,2}$, A. Hiyama ${ }^{1,2}$, T. Nakai ${ }^{2}$ and J. Mochida ${ }^{1,2, *}$ \\ ${ }^{1}$ Department of Orthopaedic Surgery, Surgical Science, Tokai University School of Medicine, Isehara, Kanagawa, \\ Japan \\ ${ }^{2}$ The Research Centre for Regenerative Medicine, Tokai University School of Medicine, Isehara, Kanagawa, Japan
}

\begin{abstract}
Transplantation of activated nucleus pulposus (NP) cells obtained by coculturing NP cells and bone marrow mesenchymal stromal cells having cell-to-cell contact has been shown to be effective in animal models and, more recently, in human clinical trials. If the NP cells can be cryopreserved, then autologous cell transplantation could be offered to patients as and when required. In a previous study, we confirmed that activated NP cells can be obtained by coculturing with mesenchymal cells after cryopreservation. However, the in vivo effects of cell transplantation therapy using activated NP cells prepared from cryopreserved cells are not known. In this in vivo canine model, we compared indicators of disc degeneration in animals that received transplanted activated normal NP cells, transplanted cryopreserved NP cells, and no cell transplantation after induction of disc degeneration. The intervertebral disc height on radiographs and $\mathrm{T}_{2}$-weighted magnetic resonance imaging were significantly higher in both cell transplantation groups compared with the degenerated disc group. Macroscopic and histological findings demonstrated attenuated disc degeneration in the two transplanted groups. Intense staining of proteoglycan and collagen type II was seen in green fluorescent proteinlabelled transplanted cells, which suggested that the cells had survived and were functioning after transplantation. No significant differences were observed between the two transplanted groups. Transplanted activated cryopreserved NP cells induced a similar attenuation of intervertebral disc degeneration as that of conventionally activated NP cells. These findings suggest that the use of cryopreserved cells specific to a patient's condition has potential in transplantation therapy.
\end{abstract}

Keywords: Intervertebral disc repair, cell transplantation, nucleus pulposus cells, bone morrow-derived mesenchymal stromal cells, cell-to-cell contact coculture, cryopreservation, activated nucleus pulposus cells.

*Address for correspondence:

Prof. Joji Mochida

Department of Orthopaedic Surgery, Surgical Science

Tokai University School of Medicine

143 Shimokasuya

Isehara Kanagawa, 259-1193, Japan

Telephone Number: +81-463-93-1121

FAX Number: +81-463-96-4404

E-mail: jomo@is.icc.u-tokai.ac.jp

\section{Introduction}

Lower back pain is a major health problem that restricts daily life activities, and has a high incidence and high prevalence. Lower back pain affects $60-80 \%$ of adults at least once in their life and imposes a great socioeconomic burden (Kelsey and White, 1980). In the United States, the costs incurred because of lower back pain exceed 100 billion dollars per year (Katz, 2006). Luoma et al. (2000) reported that lower back pain is strongly associated with degeneration of the intervertebral disc (IVD); however, a basic treatment for IVD degeneration (IDD) is yet to be established. Experimental therapies developed to treat IDD include IVD injection of cytokines or growth factors (Masuda et al., 2006), gene transfer to enhance IVD cell function (Nishida et al., 2008), transplantation of an externally prepared tissue-engineered IVD (Bowles et al., 2011), and transplantation of highly active cells directly into the IVD (Hiyama et al., 2008; Iwashina et al., 2006; Okuma et al., 2000; Sakai et al., 2003; Sakai et al., 2006; Serigano et al., 2010).

It has been reported that IDD is initially triggered by a reduction in IVD cell number (Antoniou et al., 1996). The low cell count leads to a decrease in the extracellular matrix produced by the cells, which causes reduced IVD resilience, poor biomechanical properties, and malfunction. These events along with external factors lead to structural failure. Because IVD cells live in an environment that is under a high compressive load and is low in oxygen and nutrients, it is difficult for them to survive and proliferate (Sakai, 2008).

In general, once the number of cells in the tissue is reduced because of tissue damage or degeneration, it is extremely difficult to restore the cells. One treatment for this decline in the number of functional cells is supplementation with exogenous cells such as stem cells. In various types of tissue damage, such as bone defects (Kitaori et al., 2009), myocardial infarction (Barbash et al., 2003; Kawada et al., 2004), cerebral infarction (Wang et al., 2002; Ji et al., 2004), and wound healing (Mackenzie and Flake, 2001), stem cells, including tissue-specific mesenchymal stem cells (MSCs), migrate from their pool to help restore the damaged site. However, the IVD is the largest avascular structure in the body (Riches et al., 2002) and is protected by a fibrous ring comprising multiple layers of fibrocartilagenous lamellae and a dense cartilage endplate, which limit the migration of MSCs through the blood stream toward the centre of the IVD (Sakai et al., 2014). Analyses of endogenous stem cells (Henriksson et al., 2012; Sakai et al., 2012; Henriksson et al., 2013) have 
revealed that, although IVDs can regenerate, this ability is very weak (Henriksson and Brisby, 2013). Therefore, based on these reports, we believe that supplementation with exogenous stem cells is a valid approach for inhibiting IDD and regenerating IVD cells.

Mochida et al. (1996) reported that, when performing surgery for lumbar disc herniation, it is important to minimise the extent of herniotomy and to preserve the structure of the intervertebral nucleus pulposus (NP) to prevent postoperative IDD. To ensure NP tissue homeostasis, it is believed that viable and functional NP cells are required to produce abundant amounts of proteoglycan and collagen. In the application of this knowledge to the prevention of IDD, basic and clinical research has shown that coculturing of bone marrowderived MSCs (BMSCs) in direct cell-to-cell contact with intervertebral NP cells can biologically activate the NP cells (Yamamoto et al., 2004; Watanabe et al., 2010). The safety of this procedure has been recently reported for a phase I clinical trial using this method (Mochida et al., 2015). However, given the risk of cell cultivation-induced tumorigenesis, the cultivation period following IVD extraction in the clinical trial was 7 days, which limits the scope and time frame for the application of the cells. If the NP cells can maintain their function after cryopreservation after extraction, autologous cell transplantation could be offered to patients as and when required. This would expand the scope for application of the cells without any time restriction.

Tanaka et al. (2013) conducted an experiment in which NP cells were activated successfully after cryopreservation. However, there are no reports of studies using large animals to examine how the transplantation of NP cells activated following cryopreservation affects IDD in vivo. Therefore, in the present study, we used an IDD model in the adult beagle, which is histologically similar to humans and is known to experience the spontaneous onset of IDD. We assessed the efficacy of transplantation of NP cells activated after cryopreservation. The aim of this study was to determine whether this cell transplantation method can be applied on demand for later cell transplantation therapy without any time restrictions and loss of efficacy.

\section{Materials and Methods}

\section{Study design}

This study was conducted at the author's institution in accordance with protocols approved by a committee for safe animal experimentation (Nos 132032 and 143023). We used adult chondrodystrophic canines (female beagles; age, $\sim 12$ months; body weight, $10 \mathrm{~kg} ; n=6$ ), in which the absence of lumbar disease was confirmed by plain X-ray of the lumbar spine in the true lateral view and by sagittal magnetic resonance imaging (MRI) of the lumbar spine. Degeneration was induced using the reproducible IDD model reported by Hiyama et al. (2008). The experiment was initiated by first randomly assigning the L2/3, 3/4 and $4 / 5$ IVDs in the canines to one of the three groups: the $\mathrm{N}$ group, which received normal activated NP cell transplantation; the F group, which received transplantation of activated NP cells after cryopreservation; and the D group, which did not receive any treatment and served as the degeneration control. The L5/6 vertebra comprised the normal control (NC) group without NP absorption (Fig. 1). It was important to confirm whether the transplanted cells really survived and remained functional. Because the long-term labelling of cells requires marker gene transduction and we wanted to eliminate this step from the initial experiment, activated NP cells were labelled with green fluorescent protein (GFP) and used in one beagle to confirm cell survival and function 12 weeks after transplantation $(n=1)$.

IDD was induced under general anaesthesia and in accordance with the procedures for the N, F and D groups. At the same time, NP tissue and bone marrow aspirate were collected for use in the F group. Thereafter, NP cells and BMSCs were isolated and cryopreserved. Two weeks later, bone marrow aspirate from the ilium and NP tissue from L1/2 were collected to extract cells for use in the $\mathrm{N}$ group. NP cells and BMSCs were isolated and then activated by coculture having direct cell-to-cell contact. In the D group, IVDs were subjected to NP absorption alone. The final surgery was performed 3 weeks after the first surgery, with $\mathrm{N}$ and $\mathrm{F}$ groups receiving transplantation of $1 \times 10^{6}$ cells $/ 100 \mu \mathrm{L}$ under fluoroscopy (Fig. 2). Assessment was performed on the basis of plain X-ray images of the lumbar spine in the true lateral view and $\mathrm{T}_{2}$-weighted sagittal MRI performed 4, 8 and 12 weeks after transplantation. IDD was assessed over time according to the disc height index (DHI) and changes in the $T_{2}$ signal intensity of the IVD using the Pfirrmann classification (Pfirrmann et al., 2001) on MRI. Twelve weeks after transplantation, the canines were administered a lethal dose $(120 \mathrm{mg} / \mathrm{kg})$ of sodium pentobarbital (Abbott Laboratories, Abbott Park, IL, USA). Following euthanasia, the L2/3, 3/4, 4/5 and 5/6 IVDs were extracted and examined histologically according to the macroscopic views of the sagittal slices of the IVDs. Tissue samples were stained with haematoxylin-eosin (H\&E) and Safranin O, and were subjected to immunohistochemical analysis.

\section{Disc degeneration model}

The canines were rapidly sedated with an intramuscular injection of midazolam $(0.4 \mathrm{mg} / \mathrm{kg}$, Astellas Pharma Inc., Tokyo, Japan), medetomidine (0.02 mg/kg, Kyouritsu Seiyaku Corporation, Tokyo, Japan) and butorphanol tartrate $(0.4 \mathrm{mg} / \mathrm{kg}$, Meiji Seika Pharma Co. Ltd., Tokyo, Japan). Thereafter, the canines were anaesthetised with $2.5 \%$ isoflurane inhalation. The IVDs were exposed using the left anterior approach under general anaesthesia, and NP aspiration was performed. An 18-gauge needle with a stopper was inserted through the fibrous ring into the centre of the NP, and suction was performed once using a $10-\mathrm{mL}$ syringe. The mean amount of NP harvested was $15.9 \pm 5.7 \mathrm{mg}$. There were no surgery-related complications, and no canines were left with functional impairment. Intramuscular injection of buprenorphine (0.02 mg/kg; Otsuka Pharmaceutical Co. Ltd., Tokyo, Japan) was administered as an analgesic intraoperatively. 


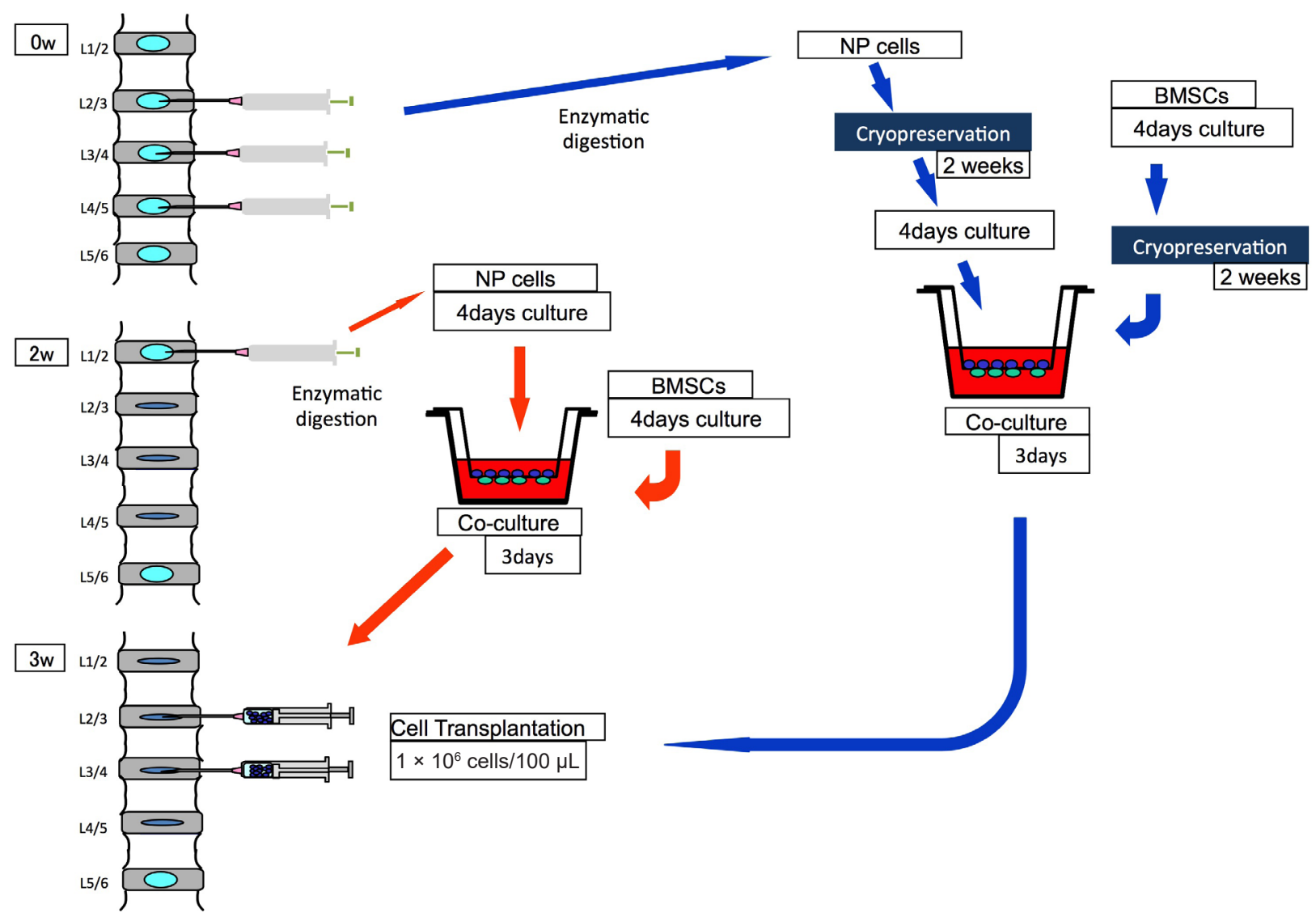

Fig. 1. Protocol of the current study is presented in the order of steps 1 through 3 for IVD cell transplantation in the $\mathrm{F}$ group (blue arrows) and steps 1 through 3 in the $\mathrm{N}$ group (red arrows). Disc degeneration was induced in L2/3, 3/4 and 4/5 discs under general anaesthesia. L5/6 discs served as the non-punctured controls. In step 1 for the F group, enzymatically isolated nucleus pulposus (NP) cells were cryopreserved for 2 weeks and then thawed and cultured in monolayers for $4 \mathrm{~d}$ before coculture. Bone marrow blood was aspirated at the same time from the iliac crest of all animals to isolate bone marrow-derived mesenchymal stromal cells (BMSCs), which were cultured for $4 \mathrm{~d}$ in plastic and then cryopreserved for 2 weeks before coculture. In step 2 for the F group, NP cells and BMSCs were cocultured with direct contact with each other through the culture insert membrane for $3 \mathrm{~d}$ to activate NP cells. BMSCs were seeded directly to coculture after thawing to match the in vitro culture period in the protocol of the previous study. In step 3 for the F group, 3 weeks after the first surgery, activated NP cells were collected and transplanted under fluoroscopic guidance into degenerated discs at a cell density of $1 \times 10^{6}$ cells $/ 100 \mu \mathrm{L}$ of medium $(\alpha-\mathrm{MEM})$. In step 1 for the N group, 2 weeks after the first surgery, NP cells were isolated from L1/2 discs to be used for N group IVD cell transplantation. BMSCs were also isolated from the bone marrow blood aspirated from the contralateral iliac crest for the first surgery. In step 2 for the N group, both NP cells and BMSCs were cultured for $4 \mathrm{~d}$ in a monolayer and then cocultured with direct contact with each other through the culture insert membrane for $3 \mathrm{~d}$ to activate NP cells. In step 3 for the N group, 3 weeks after the first surgery, activated NP cells were collected and transplanted under fluoroscopic guidance into degenerated IVDs at a cell density of $1 \times 10^{6}$ cells $/ 100 \mu \mathrm{L}$ medium $(\alpha$-MEM). The cell-transplanted IVD level for groups $\mathrm{N}$ and $\mathrm{F}$ and IVD that received induction of degeneration only (D group) was interchanged in L2/3, 3/4 and 4/5 in the animals to minimise any effects because of the use of different levels.

\section{NP cell isolation}

Harvested NP tissues were treated with $50 \%$ TrypLE Express (Gibco, Grand Island, NY, USA) in a thermostatic chamber at $37^{\circ} \mathrm{C}$ for $1 \mathrm{~h}$, followed by treatment with $0.25 \mathrm{mg} / \mathrm{mL}$ of research-grade Liberase DL (Roche, Basel, Switzerland) at $37^{\circ} \mathrm{C}$ for $2 \mathrm{~h}$. Cell culture for the $\mathrm{N}$ group was performed in accordance with the protocols used in the clinical study reported by Tanaka et al. (2013) (see the cell culture method described below). After enzymatic treatment, cells of the $\mathrm{F}$ group were cryopreserved at a cell density of $3.0 \times 10^{5}$ cells/ $\mathrm{mL}$ in $70 \% \alpha$-MEM (Gibco, Grand Island, NY, USA), $20 \%$ foetal bovine serum (FBS) (Gibco, Tokyo, Japan), and $10 \%$ dimethyl sulphoxide (Wako, Osaka, Japan). Next, the samples were cryopreserved in stages to $-80{ }^{\circ} \mathrm{C}$ using a Bicell cryopreservation device (Nihon-freezer, Tokyo, Japan). The following day, the samples were stored and maintained for 2 weeks in a liquid nitrogen container at $-196{ }^{\circ} \mathrm{C}$. Thereafter, the samples were rapidly thawed in a $37{ }^{\circ} \mathrm{C}$ water bath, washed twice in phosphate-buffered saline (PBS), and cultured at $37{ }^{\circ} \mathrm{C}$ in $5 \% \mathrm{CO}_{2}$, similar to the cells of the $\mathrm{N}$ group. The viability of NP cells after thawing was $70.3 \pm 10.3 \%$. 
Fig. 2. Cell transplantation into discs in the $\mathrm{N}$ and $\mathrm{F}$ groups was performed under fluoroscopic guidance. Under general anaesthesia, a 23-G nerve block needle was inserted from the contralateral side of the IVD where degeneration was induced. The needle was placed carefully to avoid the endplate and neural damage, and a fluoroscopic live image was used to guide the insertion of the needle into the centre of the target IVD. The syringe to deliver $1 \times 10^{6}$ cells $/ 100 \mu \mathrm{L}$ of medium was locked to the proximal end of the needle to avoid leakage.
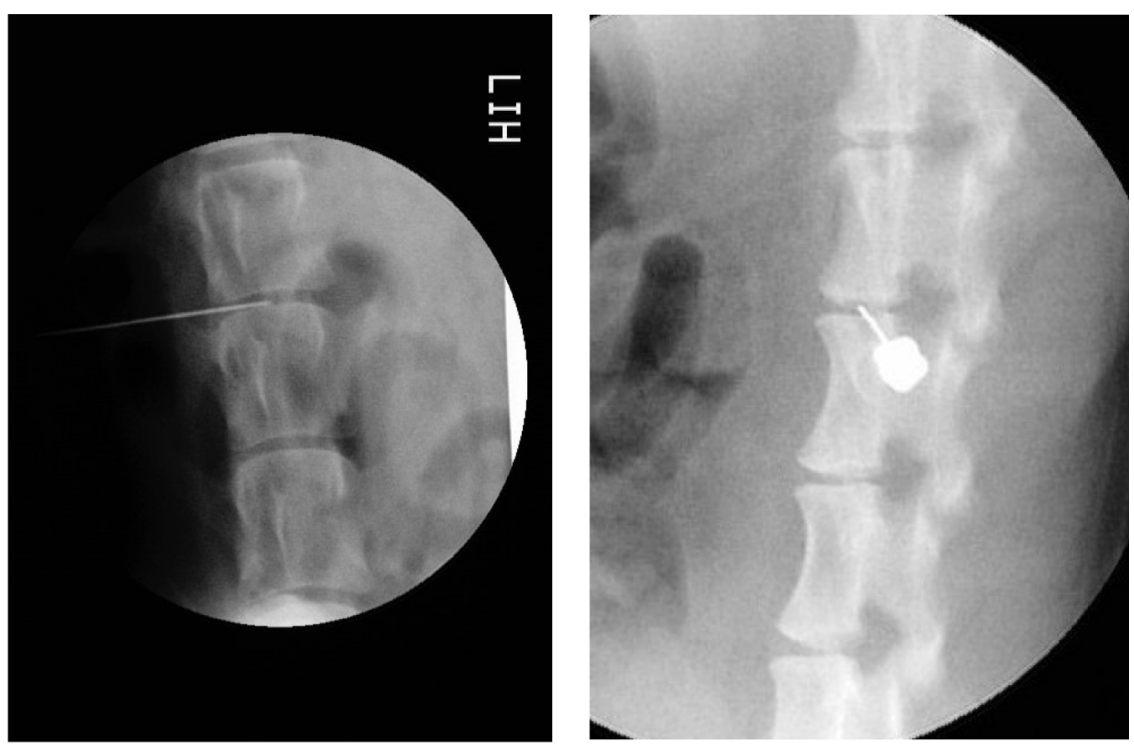

\section{Bone marrow-derived stromal cell isolation}

Using a bone marrow puncture needle, $25 \mathrm{~mL}$ of bone marrow aspirate was collected from the ilium intraoperatively and mixed with $2 \mathrm{~mL}$ of heparin. The bone marrow aspirate collected from the ilium was separated by specific gravity using a saline- $5 \%$ dextran solution, after which the mononuclear cells were isolated. The mononuclear cells were cultivated for $4 \mathrm{~d}$ in a $100-\mathrm{cm}^{2}$ culture flask in $\alpha$-MEM culture medium containing $10 \%$ FBS. Adherent cells were considered to be BMSCs. After $4 \mathrm{~d}$ of cultivation, cells of the F group were removed using TrypLE Express (Gibco, Grand Island, NY, USA) and cryopreserved using the same procedure and timeframe as that for the NP cells. The samples were thawed rapidly in a $37^{\circ} \mathrm{C}$ bath and cultured, similar to the cells of the $\mathrm{N}$ group. The viability of BMSCs after thawing was $90.4 \pm 5.2 \%$

\section{Coculture method for obtaining activated NP cells}

A monolayer of seeded NP cells was cultured at $3.0 \times 10^{4}$ cells/mL per well in a six-well plate (Becton Dickinson, Franklin Lakes, NJ, USA) for $4 \mathrm{~d}$ at $37^{\circ} \mathrm{C}$ in $5 \% \mathrm{CO}_{2}$. A monolayer of mononuclear cells isolated from the bone marrow was also cultured in a $100-\mathrm{cm}^{2}$ culture flask. A six-well plate with inserts (pore size, $0.4 \mu \mathrm{m}$ ) (Becton Dickinson) was used for coculture. First, BMSCs were seeded and cultured on the reverse side of the inserts at $3.0 \times 10^{4}$ cells $/ \mathrm{mL}$ per well. Three hours later, the inserts were set into the six-well plate and NP cells were seeded on the top of each insert at $3.0 \times 10^{4}$ cells $/ \mathrm{mL}$ per well. To induce direct cell-to-cell contact, the cells were cocultured in $\alpha$-MEM culture medium containing $10 \%$ FBS for $3 \mathrm{~d}$ at $37^{\circ} \mathrm{C}$ in $5 \% \mathrm{CO}_{2}$ (Fig. 1 ).

\section{Viral transfection of GFP into activated NP cells}

To label activated NP cells before transplantation, adenoassociated viral infection of the AcGFP1 gene was performed. Proliferating activated NP cells were cultured and washed with PBS, and virus stock was added to each dish according to the manufacturer's instructions (Takara
Bio Inc., Otsu, Japan). Vector incorporation was $\sim 65 \%$ as assessed by flow cytometry.

\section{Cell transplantation}

Similar to the method used to induce degeneration, the canines were positioned in a left lateral decubitus position under general anaesthesia, and cell transplantation was performed using a $23-\mathrm{G}$ nerve block needle under fluoroscopy from a right posterior approach (Fig. 2).

\section{Evaluations}

\section{Radiological assessment}

Plain lumbar X-ray imaging of all canines was performed with the animal under inhalation anaesthesia at 0 weeks (before surgery), at the time of cell transplantation, and then 4,8 and 12 weeks following cell transplantation. Images were taken using a fluoroscopic imaging intensifier $(70 \mathrm{kV}$, $10 \mathrm{~mA}$, distance $100 \mathrm{~cm}$ ). Vertebral body height and IVD height were measured using ImageJ software, and data were transferred to the Excel program (Microsoft Excel). The DHI was calculated using the method of Masuda et al. (2006). Changes in DHI were expressed as \%DHI and were standardised to the preoperative DHI as follows: $\% \mathrm{DHI}=[($ postoperative $\mathrm{DHI} /$ preoperative $\mathrm{DHI}) \times 100]$.

\section{MRI assessment}

$\mathrm{T}_{2}$-weighted MRI in the sagittal plane was performed at 0 weeks (before surgery) and then 4,8 and 12 weeks following cell transplantation. In all cases, MRI was performed using an Achieva 1.5 T instrument (Philips, Amsterdam, Netherlands). $\mathrm{T}_{2}$-weighted sections in the sagittal plane were obtained using a fast spin-echo sequence with time to repetition of $3500 \mathrm{~ms}$, time to echo of $120 \mathrm{~ms}$, interslice gap of $1.0 \mathrm{~mm}$, matrix of $336 \times 240$, field of view of $300 \mathrm{~mm} \times 300 \mathrm{~mm}$, number of excitations of 17 , and turbo spin-echo spacing set at $13.3 \mathrm{~mm}$. Twelve weeks following cell transplantation, the signal intensity of all IVDs on $\mathrm{T}_{2}$-weighted images was assessed according to the Pfirrmann classification (Pfirrmann et al., 2001). Two 


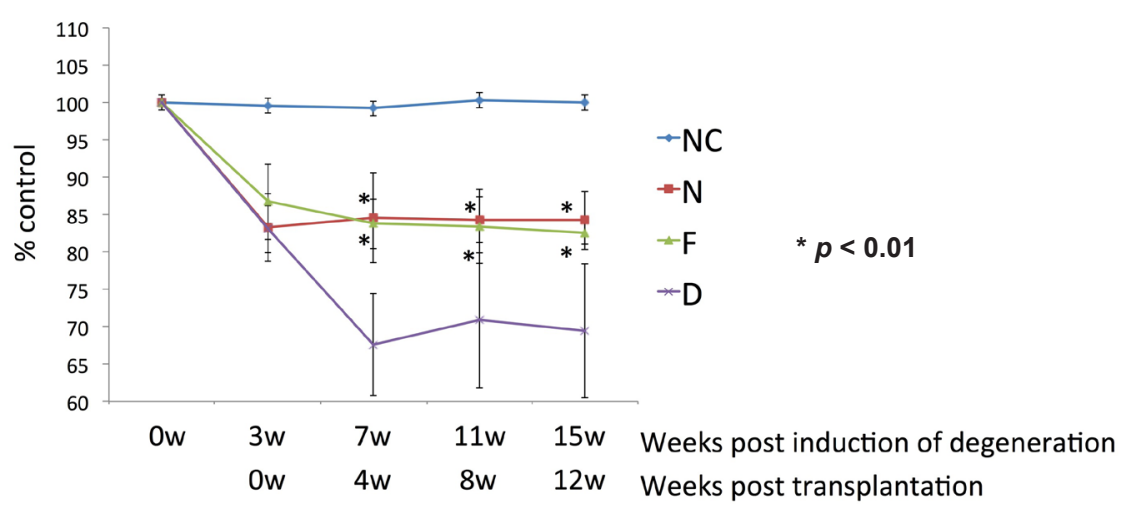

Fig. 3. Radiological assessment of activated NP cell transplantation. Radiographs showed significant narrowing of the disc space at 3 weeks after induction of IVD degeneration in the $\mathrm{D}, \mathrm{N}$ and $\mathrm{F}$ groups $(p<0.01)$. The preservation of the disc height index (\%DHI) was nearly $100 \%$ in the NC group throughout the study. The mean $\% \mathrm{DHI}$ in the D group continued to decrease until 7 weeks after induction and then plateaued. By contrast, at 4, 8 and 12 weeks after transplantation, \%DHI was significantly better maintained in the $\mathrm{N}$ and $\mathrm{F}$ groups compared with the D group. No significant differences were seen between the $\mathrm{N}$ and $\mathrm{F}$ groups at $0,4,8$ and 12 weeks. The mean $\% \mathrm{DHI}$ was reduced to $69.4 \%$ in the $\mathrm{D}$ group, $84.2 \%$ in the $\mathrm{N}$ group and to $82.6 \%$ in the F group 12 weeks after cell transplantation. The respective values were: $\mathrm{NC}$ group: $99.6 \pm 0.3 \%, 99.2 \pm 1.1 \%, 100.3 \pm 0.9 \%$ and $100.0 \pm 1.3 \%$; N group: $83.3 \pm 4.6 \%, 84.6 \pm 6.0 \%, 84.3 \pm 3.0 \%$ and $84.2 \pm 3.9 \%$; F group: $86.8 \pm 5.0 \%, 83.8 \pm 3.3 \%, 83.4 \pm 5.0 \%$ and $82.6 \pm 1.8 \%$; and D group: $83.0 \pm 3.2 \%, 67.6 \pm 6.9 \%, 70.8 \pm 9.0 \%$ and $69.4 \pm 9.0 \%$.

observers familiar with human and animal IVD specimens and blinded to this study evaluated the MRI images.

\section{Gross anatomical findings}

The vertebral bodies and IVDs collected from the seven canines ( $n=28$ IVDs) were fixed in $4 \%$ paraformaldehyde and left in decalcifying solution A (Wako, Osaka, Japan) for $7 \mathrm{~d}$. Specimens were sliced in the longitudinal plane so that the cut passed through the centre of the IVD for macroscopic evaluation.

\section{Histological examination}

Each IVD collected was fixed in $4 \%$ paraformaldehyde, left to decalcify, and embedded in paraffin. The paraffin blocks were stained with H\&E and Safranin O, followed by histological examination. In H\&E-stained sections, degeneration of the fibrous ring was assessed using the IDD classification system of Nishimura and Mochida (1998). Two observers familiar with human and animal IVD specimens and blinded to this study evaluated the sections.

\section{Immunohistochemistry staining}

Immunohistochemistry was performed using sections obtained from activated NP cell-transplanted discs 12 weeks after transplantation. Before staining with the designated primary antibodies, sections were blocked with $5 \%$ bovine serum albumin (BSA)-PBS ( $3 \%$ BSA, $0.02 \%$ Tween $20,0.02 \% \mathrm{NaN}_{3}$ in PBS) for $30 \mathrm{~min}$ at room temperature. The primary antibodies used were against the following antigens (dilutions): proteoglycan (MAB2015, 1:200; Chemicon, Temecula, CA, USA); type II collagen (mIgG2, 1:100; Daiichi Fine Chemical, Takaoka, Japan); and GFP (rabbit, ab290, 1:200; Abcam, Cambridge, UK). Species-specific secondary antibodies were used for double labelling: Alexa 488 and 594 (1:200; Molecular Probes, Eugene, OR, USA) or the standard method using horseradish peroxidase and 3,3'-diaminobenzidine tetrahydrochloride. Tissues were mounted onto slides with VECTASHIELD Mounting Medium with 4, 6-diamino-2phenylindole (DAPI) (Vector Laboratories, Burlingame, CA, USA). Sections were digested by $0.005 \%$ Proteinase (Sigma-Aldrich, Saint Louis, MO, USA)/ Tris-HCl buffer $\mathrm{pH} 7.6$ for $10 \mathrm{~min}$ at $37^{\circ} \mathrm{C}$ before type II collagen staining. Two pathologists counted the cells in the nucleus pulposus area in 10 random HPFs (High power fields, magnification $\times 400$ ). The percentage of GFP-positive cells of the total nucleus pulposus cells was calculated.

\section{Statistical analyses}

Analysis of variance and Fisher's protected least-significant difference post hoc tests were used to identify significant differences in \%DHI on X-ray images in the lateral view, MRI results, and histological examination. Mann-Whitney U-test was used to analyse the rate of the GFP-positive cells. Statistical analyses were performed using SPSS software (IBM, Armonk, NY, USA). Error bars represent 1 $\mathrm{SD}$ and differences of $p<0.05$ were considered significant.

\section{Results}

\section{Radiographic findings}

Radiographs showed significant narrowing of the disc space at 3 weeks after induction of IVD degeneration in the $\mathrm{D}, \mathrm{N}$ and $\mathrm{F}$ groups $(p<0.01)$. The preservation of the disc height index (\%DHI) was nearly $100 \%$ in the NC group throughout the study. The mean $\% \mathrm{DHI}$ in the D group continued to decrease until 7 weeks after induction and then plateaued. By contrast, at 4, 8 and 12 weeks after transplantation, \%DHI was significantly better maintained in the $\mathrm{N}$ and $\mathrm{F}$ groups compared with the $\mathrm{D}$ group. No significant differences were seen between the $\mathrm{N}$ and $\mathrm{F}$ groups at $0,4,8$ and 12 weeks. The mean $\% \mathrm{DHI}$ was reduced to $69.4 \%$ in the D group, $84.2 \%$ in the $\mathrm{N}$ 
a

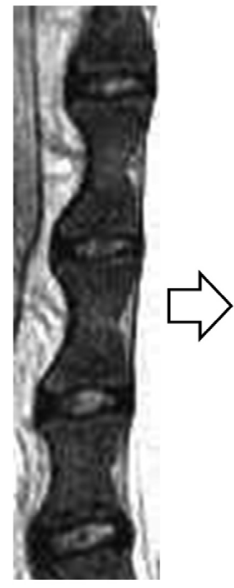

Ow

b

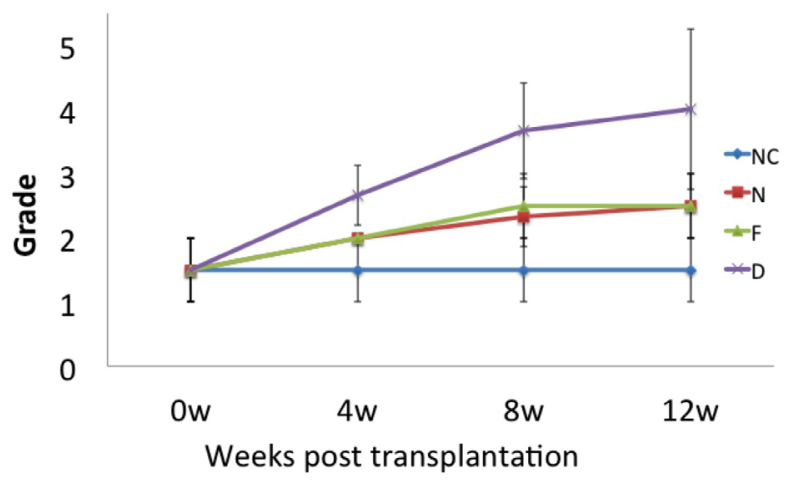

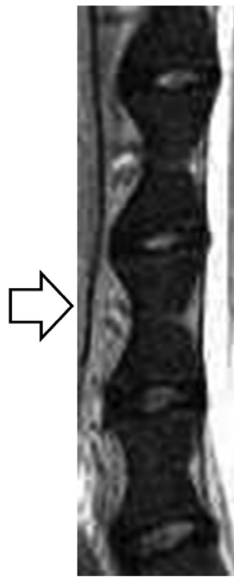

$8 w$ C

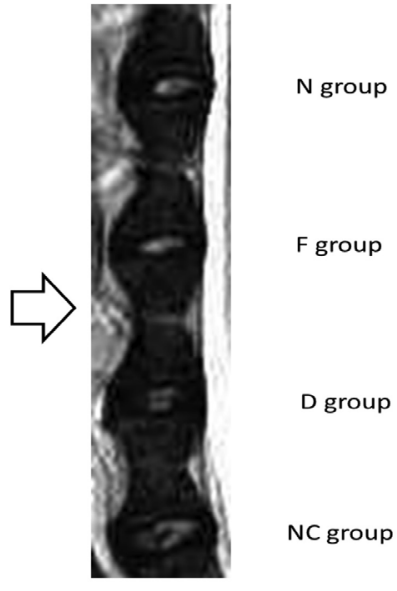

$12 \mathrm{w}$

MRI(Pfirrmann classification)

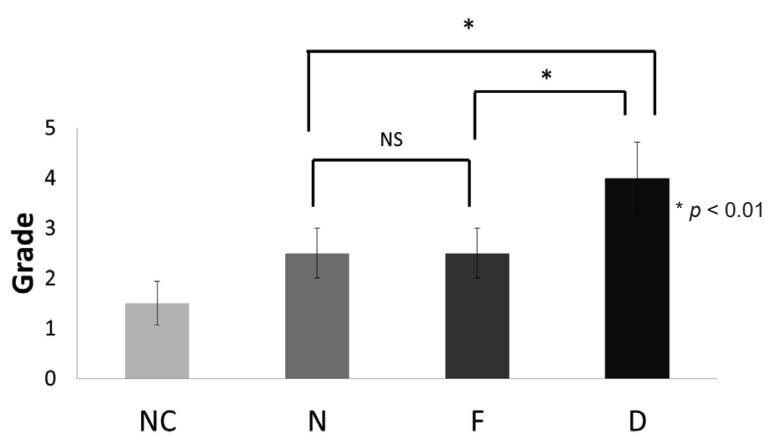

Fig. 4. MRI analysis showing signal changes in $\mathrm{T}_{2}$-weighted images at 12 weeks after transplantation analysed according to the Pfirrmann classification. ( $(\mathbf{a}$ and $\mathbf{b})$ Sequential results indicated that the NC group displayed no changes in the signal intensity of the IVD NP on $\mathrm{T}_{2}$-weighted MRI images. In the D group, the signal intensity decreased gradually after NP aspiration-induced degeneration. By contrast, the $\mathrm{N}$ and $\mathrm{F}$ groups showed no changes in the signal intensity of the IVD NP compared to pre-transplant values. At 12 weeks after transplantation, the N and F groups maintained grades 2-3 on the Pfirrmann classification, whereas the D group displayed grades 3-5, which indicated progressive degeneration. (c) Grading according to the Pfirrmann classification revealed that $\mathrm{N}$ and $\mathrm{F}$ groups showed significantly maintained $\mathrm{T}_{2}$-weighted $\mathrm{MRI}$ values in the transplant groups. No significant differences were detected between the $\mathrm{N}$ and $\mathrm{F}$ groups (NC: $1.5 \pm 0.4, \mathrm{~N}: 2.5 \pm 0.5, \mathrm{~F}: 2.5 \pm 0.5$ and $\mathrm{D}: 4.0 \pm 0.7$ ).

group and to $82.6 \%$ in the F group 12 weeks after cell transplantation (Fig. 3).

\section{MRI findings}

Sequential results indicated that the NC group displayed no changes in the signal intensity of the IVD NP on $\mathrm{T}_{2}$-weighted MRI images. In the $\mathrm{D}$ group, the signal intensity decreased gradually after NP aspiration-induced degeneration. By contrast, the $\mathrm{N}$ and $\mathrm{F}$ groups showed no changes in the signal intensity of the IVD NP compared to pre-transplant values. At 12 weeks after transplantation, the $\mathrm{N}$ and $\mathrm{F}$ groups maintained grades 2-3 on the Pfirrmann classification (Pfirrmann et al., 2001), whereas the D group displayed grades 3-5, which indicated progressive degeneration (Fig. 4 a,b). Grading according to the Pfirrmann classification revealed that $\mathrm{N}$ and $\mathrm{F}$ groups showed significantly maintained $\mathrm{T}_{2}$-weighted MRI values in the transplant groups. No significant differences were detected between the $\mathrm{N}$ and $\mathrm{F}$ groups (Fig. 4 c).

\section{Gross anatomical findings}

In the $\mathrm{N}$ and $\mathrm{F}$ groups, the discs showed an oval-shaped gel-like nucleus pulposus (NP) similar to that found in the $\mathrm{NC}$ group, whereas the discs from the $\mathrm{D}$ group showed disc space narrowing and disappearance of the NP structure and connective tissue penetrating from the surrounding tissue. (Fig. 5).

\section{Histology}

Histological examination revealed that cell transplantation had a preventive effect against disc degeneration. H\&E staining revealed that normal-looking discs in the $\mathrm{NC}$ group displayed an intact annulus fibrosus (AF) with a normal pattern of fibrocartilage lamellae and a well-defined border between the NP and AF. H\&E staining of the N and $\mathrm{F}$ group discs showed a relatively well-preserved ovalshaped nucleus with no collapse of the inner and outer annular structures of the discs compared with D group discs, which showed a severely reversed contour of the 


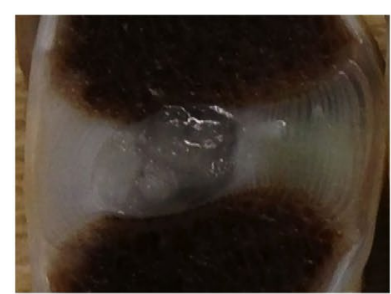

NC

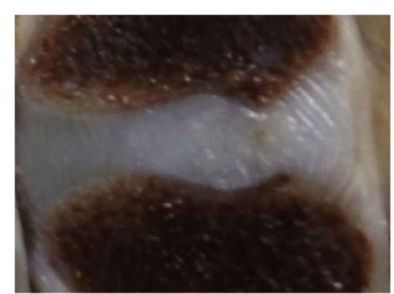

$\mathrm{N}$

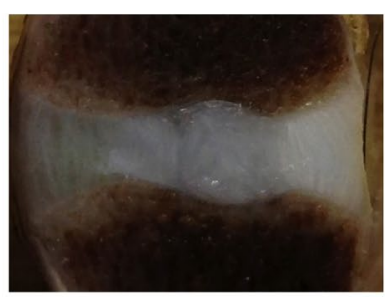

$\mathrm{F}$

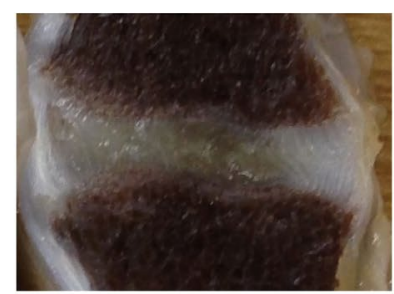

D

Fig. 5. Gross anatomical findings at 12 weeks after transplantation. In the $\mathrm{N}$ and $\mathrm{F}$ groups, the discs showed an ovalshaped gel-like nucleus pulposus (NP) similar to that found in the NC group, whereas the discs from the D group showed disc space narrowing and disappearance of the NP structure and connective tissue penetrating from the surrounding tissue.

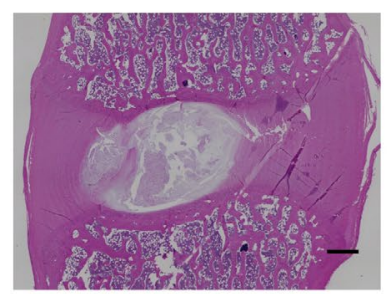

NC

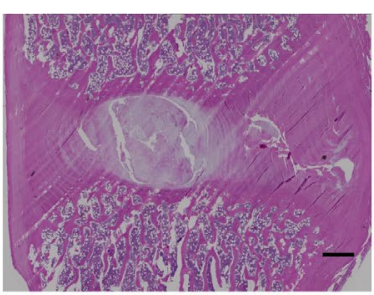

$\mathrm{N}$

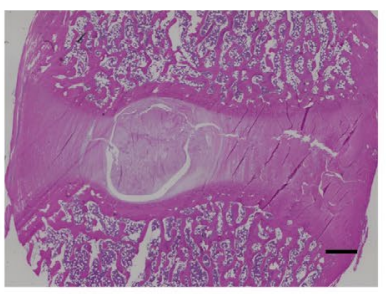

$\mathrm{F}$

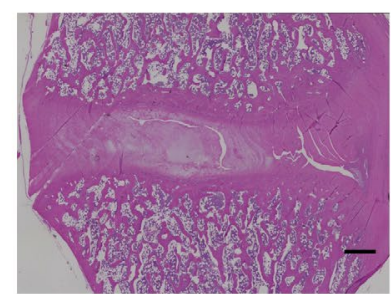

D

Fig. 6. Histology. Normal-looking discs in the NC group displayed an intact annulus fibrosus (AF) with a normal pattern of fibrocartilage lamellae and a well-defined border between the NP and AF. Haematoxylin and eosin staining of the $\mathrm{N}$ and $\mathrm{F}$ group discs showed a relatively well-preserved oval-shaped nucleus with no collapse of the inner and outer annular structures of the discs compared with D group discs, which showed a severely reversed contour of the inner AF. Bar $=1000 \mu \mathrm{m}$.

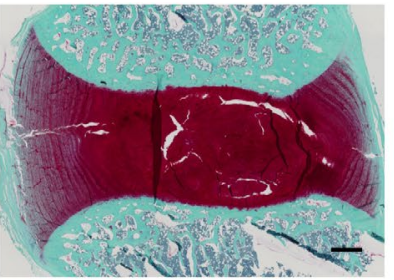

NC

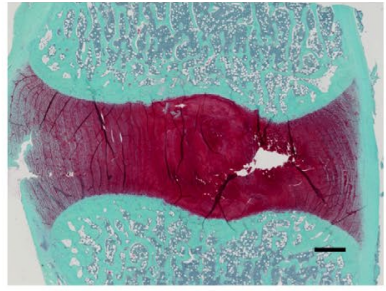

$\mathrm{N}$

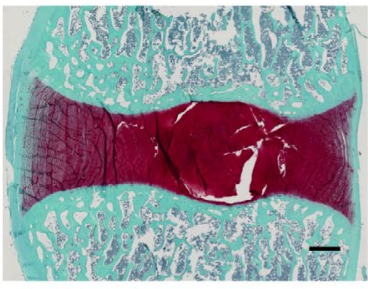

$\mathrm{F}$

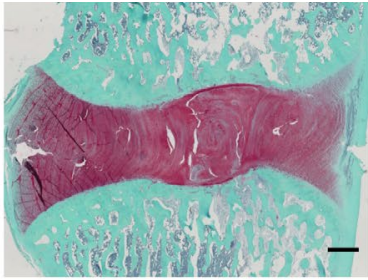

D

Fig. 7. Safranin O staining. Safranin O staining showed intense staining in the $\mathrm{N}$ and $\mathrm{F}$ groups, and less staining in the D group. These findings suggest that activated NP cell transplantation effectively attenuated the decrease in the proteoglycan content in degenerated discs. Bar $=1000 \mu \mathrm{m}$.

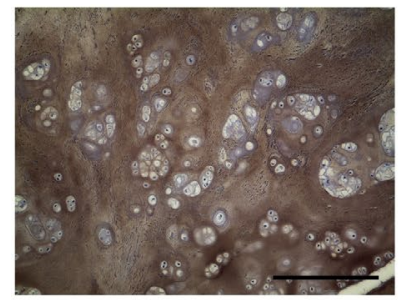

NC

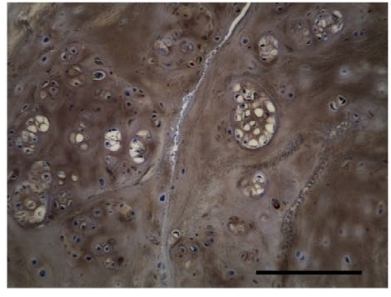

$\mathrm{N}$

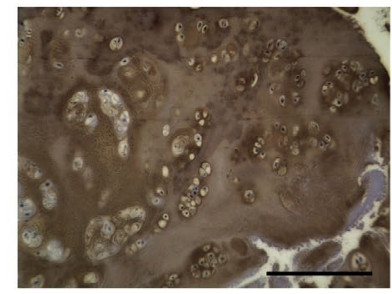

$\mathrm{F}$

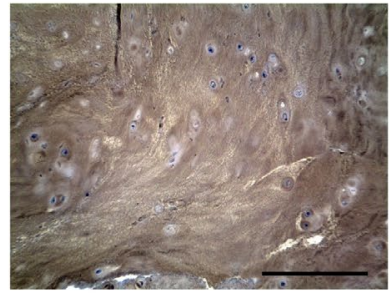

D

Fig. 8. Immunohistochemical staining for collagen type II. Staining for collagen type II showed robust intense staining in the nucleus pulposus (NP) in the N and F group discs, which was similar to that in the NC group. D group discs showed little staining of the NP. Bar $=200 \mu \mathrm{m}$.

inner AF (Fig. 6). Safranin O staining showed intense staining in the $\mathrm{N}$ and $\mathrm{F}$ groups, and less staining in the $\mathrm{D}$ group (Fig. 7). Staining for collagen type II showed robust intense staining in the nucleus pulposus (NP) in the $\mathrm{N}$ and F group discs, which was similar to that in the NC group. D group discs showed little staining of the NP (Fig. 8). At 12 weeks after transplantation, the entire $\mathrm{NC}$ group was evaluated as grade 0 according to the IDD classification of Nishimura and Mochida (1998), whereas the N, F and D groups had mean grades of $1.5,1.83$ and 4.17 , respectively. Annular structures were significantly $(p<0.01)$ better maintained in the $\mathrm{N}$ and $\mathrm{F}$ groups compared with the $\mathrm{D}$ group. No significant differences were detected between the $\mathrm{N}$ and $\mathrm{F}$ groups (Fig. 9). 
a

Degenerative changes in the annulus fibrosus

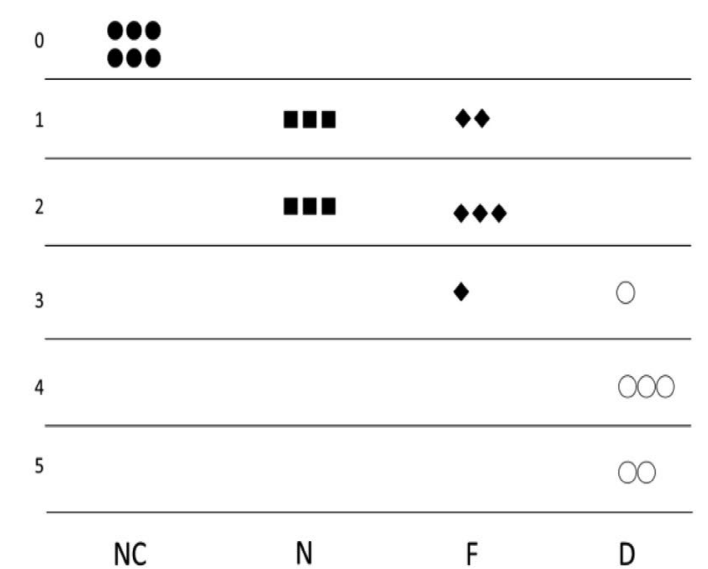

Grade 0: normal structure

Grade 1: mildly serpentine with rupture

Grade 2: moderately serpentine with rupture

Grade 3: severely serpentine with mildly

reversed contour

Grade 4: severely reversed contour

Grade 5: indistinct

Nishimura and Mochida (1998)

Histological Score (Nishimura and Mochida classification)

b

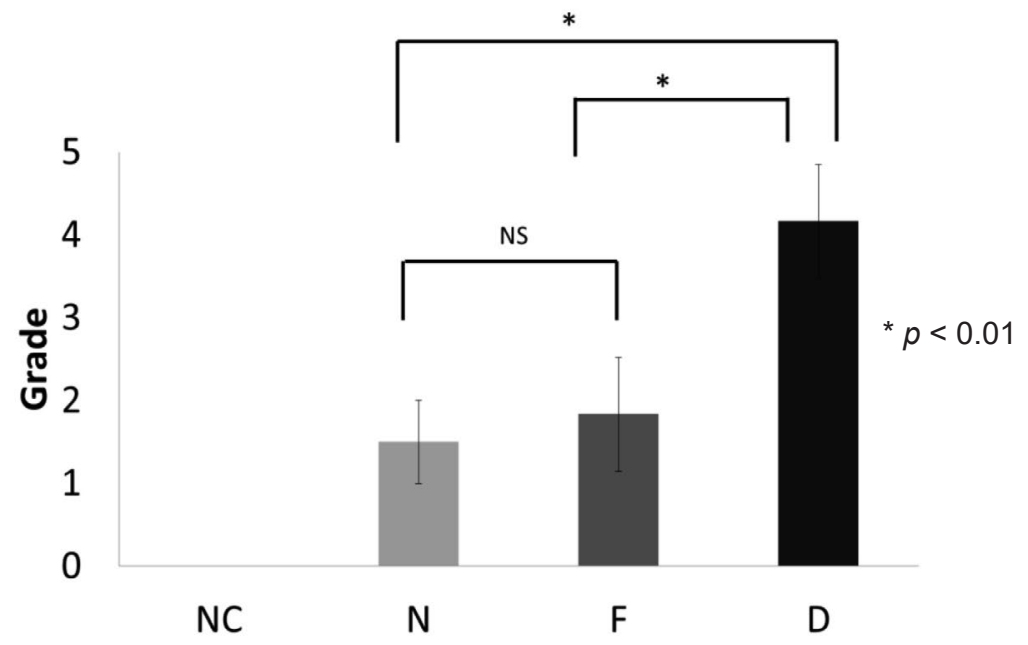

Fig. 9. Histological grading. (a) Histological analysis using the disc degeneration grading system of Nishimura and Mochida to measure morphological changes in the annular structure showed marked regenerative effects 12 weeks after cell transplantation. (b) At 12 weeks after transplantation, the entire NC group was evaluated as grade 0 according to the IDD classification of Nishimura and Mochida (1998), whereas the N, F and D groups had mean grades of 1.5, 1.83 and 4.17, respectively. Annular structures were significantly $(p<0.01)$ better maintained in the $\mathrm{N}$ and $\mathrm{F}$ groups compared with the D group. No significant differences were detected between the $\mathrm{N}$ and $\mathrm{F}$ groups (NC: $0 \pm 0 ; \mathrm{N}$ : $1.5 \pm 0.5 ; \mathrm{F}: 1.83 \pm 0.69 ; \mathrm{D}: 4.17 \pm 0.69)$.

\section{Survival and function of transplanted activated NP cells \\ Transplanted green fluorescence protein (GFP)-positive cells were seen in the central region of the nucleus pulposus (NP) in the $\mathrm{N}$ and $\mathrm{F}$ groups (Fig. $10 \mathbf{a}, \mathbf{b}$ ). Intense staining of collagen type II and proteoglycan were detected around GFP-positive cells (Fig. 10 c,d). These findings support the observation that activated NP cells could survive and function for 12 weeks after transplantation and produced extracellular matrix in the degenerated discs.}

The percentages of GFP-positive cells

GFP-positive cells were consecutively counted in 10 randomly selected visual fields of nucleus pulposus area and averaged after co-staining with GFP to detect the labelled transplanted activated NP cells. The percentage of GFP-positive cells for the N group was $21.4 \pm 1.2 \%$ and the F group $21.6 \pm 1.0 \%$. No significant differences were detected between the $\mathrm{N}$ and $\mathrm{F}$ groups (Fig.11).

\section{Discussion}

In general, in the haematopoietic stem cell support mechanism, intercellular contact is important for BMSCs to play a feeder cell role, and this may facilitate faster signal transmission from haematopoietic stem cells (Degrassi et al., 1993; Sardonini and $\mathrm{Wu}, 1993$; Kadereit et al., 2002; Minges Wols et al., 2002; Mizuguchi et al., 2002). Similarly, coculturing cells to induce direct cell-to-cell contact between NP cells and human autologous MSCs, which adhere to the $0.4 \mu \mathrm{m}$-pore size membrane, increases cell proliferation, DNA synthesis, and proteoglycan synthesis in NP cells compared with monolayer culture 
a

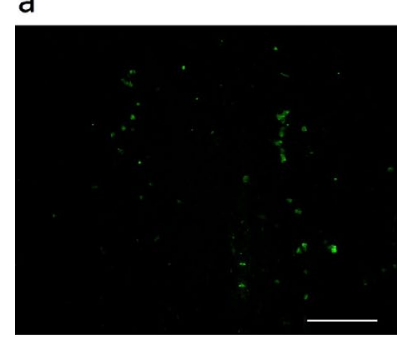

N

C

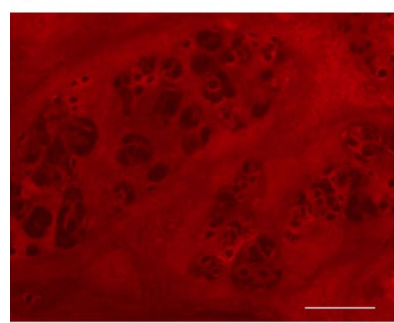

NC

d

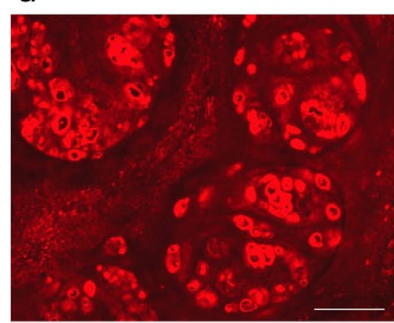

NC
GFP

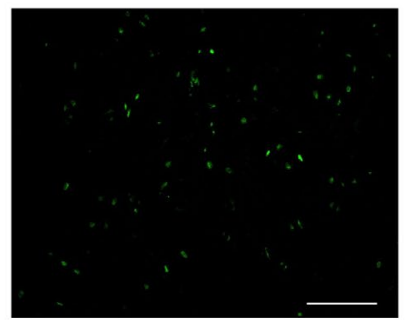

F

GFP + Collagen type II

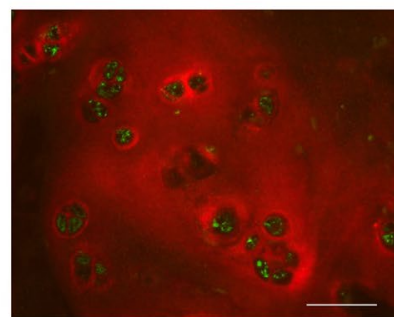

N

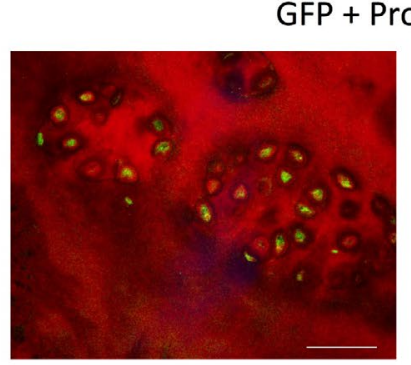

N

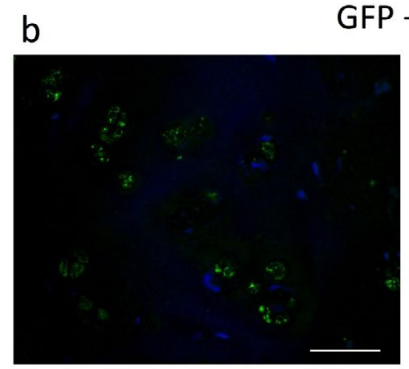

$\mathrm{N}$

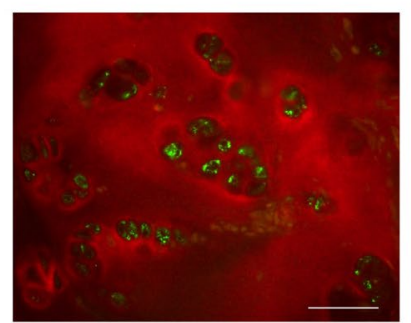

$\mathrm{F}$

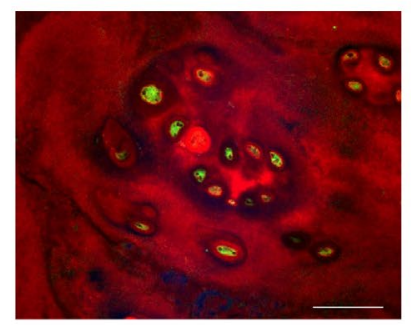

$\mathrm{F}$
GFP + DAPI

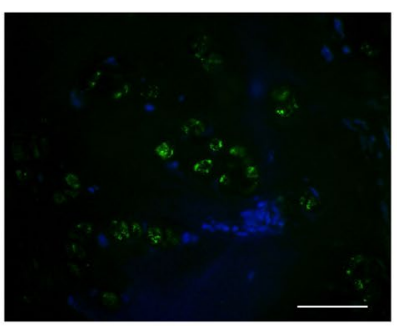

F

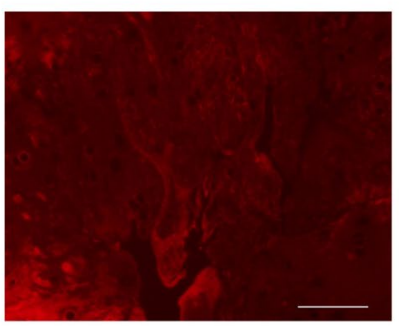

D

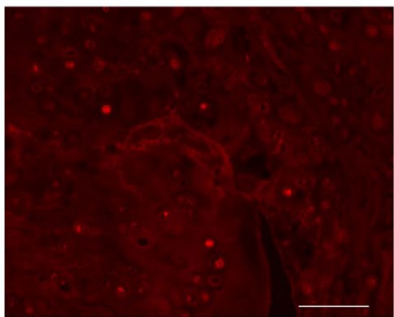

D

Fig. 10. Survival and function of transplanted activated NP cells. (a and $\mathbf{b})$ Transplanted green fluorescence protein (GFP)-positive cells were seen in the central region of the nucleus pulposus (NP) in the N and F groups. (c and d) Intense staining of collagen type II and proteoglycan were detected around GFP-positive cells. These findings support the observation that activated NP cells could survive and function for 12 weeks after transplantation and produced extracellular matrix in the degenerated discs. Bar $=100 \mu \mathrm{m}(\mathbf{a}), 50 \mu \mathrm{m}(\mathbf{b}-\mathbf{d})$.

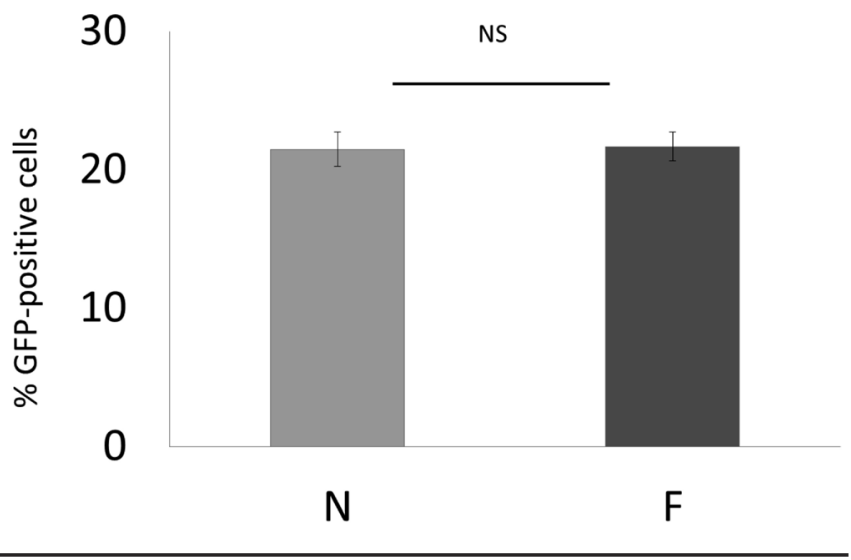

of rabbit and human cells (Yamamoto et al., 2004; Watanabe et al., 2010). Tanaka et al. (2013) analysed in beagle and human cells classified into three groups: activated NP cells cultured normally, cryopreserved cells, and cryopreserved tissue. They reported that the cell proliferation, glycosaminoglycan synthesis, and colonygenerating capacities did not differ significantly between these three groups and that there were no differences in gene expression or tumorigenic ability. Although no difference was observed in any metric between the three groups in terms of normal cultivation and cell cryopreservation, a lower cellular activity was observed in the tissue cryopreservation group (Tanaka et al., 2013). However, the in vivo effects of cryopreservation are not known.

Studies using animal models of cell transplantation to treat IDD have examined various cells including NP cells, disc chondrocytes, cartilage chondrocytes, BMSCs, adipose 
MSCs, and synovial MSCs (Ganey et al., 2003, 2009; Gorensek et al., 2004; Hiyama et al., 2008; Hoogendoorn et al., 2008; Miyamoto et al., 2010; Nishimura and Mochida, 1998; Nomura et al., 2001; Okuma et al., 2000; Sakai et al., 2003, 2005, 2006; Serigano et al., 2010). In particular, the use of MSCs has been reported in various animal models (Sakai et al., 2003, 2005, 2006; Hiyama et al., 2008; Serigano et al., 2010), and clinical trials on the use of MSCs in humans are currently underway (Yoshikawa et al., 2010; Orozco et al., 2011). However, MSCs are a heterogeneous cell population, and the extent of transplanted cell engraftment, differentiation and functioning in the host tissue can vary because of individual differences and the type of surgical procedure used. Furthermore, it has been reported that MSCs can differentiate into three cell types (bone, cartilage, and fat) and, therefore, cells that leak from the IVD after transplantation may differentiate into bone or produce osteophytes (Vadalà et al., 2012). The true effect of MSC transplantation in humans may be masked by such variability in cell populations and differentiation. Therefore, further clinical studies should be conducted to clarify the true effect of the procedure.

In the present study, the activation of NP cells after cryopreservation shows that this procedure may have prevented IVD space narrowing and maintained the $T_{2}-$ weighted signal intensity on MRI. The histological grading also confirmed the retention of the NP and annulus fibrosis structures after activated NP cell transplantation regardless of whether the cells had undergone cryopreservation or not. Sufficient engraftment was demonstrated by GFP labelling, and the engrafted cells were shown to produce proteoglycan and type II collagen up to 12 weeks after transplantation. Autologous transplantation seemed to be safe and all transplantations were completed without apparent adverse effects, such as the unintended differentiation of the transplanted cells. Our findings that these outcomes can occur even after cryopreservation suggest the potential of this procedure to be applied to various pathologies of IDD. Activated NP cell transplantation has been confirmed to be a safe procedure in humans (Mochida et al., 2015), and activated NP cells after cryopreservation have minimal risk regarding tumorigenesis (Tanaka et al., 2013), and efficacy of transplantation of activated NP cells after cryopreservation has been confirmed by a large animal model. These results provide insights into expanding the scope of application of activated NP cell transplantation to cover various spinal pathologies and to transplant activated NP cells from a cryopreserved cell bank.

If this procedure can be used at any time that the patient may be in need of cell therapy, it may be used in treating patients with IDD following IVD herniotomy or with adjacent segment disease following fusion surgery, or even in patients given a long fusion because of, for example, scoliosis. The advantage of autologous transplantation is the minimisation or, theoretically, complete lack of an immunological reaction. Thus, many patients with IVD disease may find relief from this procedure. However, in the autologous format, limitation lies with the need for prior nucleotomy/herniotomy. Therefore, cell transplantation in an allogeneic format maybe ideal to cover various pathologies.
The present study demonstrated the in vivo functioning of activated NP cells regardless of whether the cells were cryopreserved or not. This was shown to occur in a large animal - the beagle - whose IDD is similar to that in humans. A limitation of our study is that the cells and the individual animals used in the experiment were healthy and active adult canines. The outcomes for humans with IDD can only be verified with well-controlled clinical trials.

\section{Conclusion}

The present study demonstrated that, in a large animal model, transplantation of activated NP cells that had been cryopreserved and thawed before being transplanted into the IVD maintained their morphology and prevented or attenuated IVD degeneration after nucleotomy. After engraftment, the functional transplanted cells continued to produce extracellular matrix. We suggest that, in the future, NP cells and MSCs of patients who are about to undergo IVD herniotomy or spinal fusion should be cryopreserved so that they may be reintroduced later into the IVD to prevent IDD.

\section{Acknowledgments}

The authors would like to thank Tomoko Uno, Sachie Tanaka, Katsuko Naito, Yoshihiko Nakamura and the Support Center for Medical Research and Education, Tokai University School of Medicine, for their technical assistance. This work was supported in part by a Grant from AO Spine International to D.S. We confirm that the authors have no conflicts of interest to declare and there has been no significant financial support for this work that could influence its outcome.

\section{References}

Antoniou J, Steffen T, Nelson F, Winterbottom N, Hollander AP, Poole RA, Aebi M, Alini M (1996) The human lumbar intervertebral disc: evidence for changes in the biosynthesis and denaturation of the extracellular matrix with growth. J Clin Invest 98: 96-1003.

Barbash IM, Chouraqui P, Baron J, Feinberg MS, Etzion S, Tessone A, Miller L, Guetta E, Zipori D, Kedes LH, Kloner RA, Leor J (2003) Systematic delivery of bone marrow-derived mesenchymal stem cells to the infarcted myocardium: feasibility, cell migration, and body distribution. Circulation 108: 863-868.

Bowles RD, Gebhard HH, Härtl R, Bonassar LJ (2011) Tissue-engineered intervertebral discs produce new matrix, maintain disc height, and restore biomechanical function to the rodent spine. Proc Natl Acad Sci USA 108: 1310613111.

Degrassi A, Hilbert DM, Rudikoff S, Anderson AO, Potter M, Coon HG (1993) In vitro culture of primary plasmacytomas requires stem cell feeder layers. Proc Natl Acad Sci USA 90: 2060-2064.

Ganey T, Libera J, Moos V, Alasevic O, Fritsch KG, Meisel HJ, Hutton WC (2003) Disc chondrocyte transplantation in a canine model: a treatment for 
degenerated or damaged intervertebral disc. Spine 28: 2609-2620.

Ganey T, Hutton WC, Moseley T, Hedrick M, Meisel HJ (2009) Intervertebral disc repair using adipose tissuederived stem and regenerative cells: experiments in a canine model. Spine 34: 2297-2304.

Gorensek M, Jaksimović C, Kregar-Velikonja N, Gorensek M, Knezevic M, Jeras M, Pavlovcic V, Cör A (2004) Nucleus pulposus repair with cultured autologous elastic cartilage derived chondrocytes. Cell Mol Biol Lett 9: 363-373.

Henriksson HB, Brisby H (2013) Development and regeneration potential of the mammalian intervertebral disc. Cells Tissues Organs 197: 1-13.

Henriksson HB, Svala E, Skioldebrand E, Lindahl A, Brisby H (2012) Support of concept that migrating progenitor cells from stem cell niches contribute to normal regeneration of the adult mammal intervertebral disc: a descriptive study in the New Zealand white rabbit. Spine 37: 722-732.

Henriksson HB, Lindahl A, Skioldebrand E, Junevik K, Tängemo C, Mattsson J, Brisby H (2013) Similar cellular migration patterns from niches in intervertebral disc and in knee-joint regions detected by in situ labeling an experimental study in the New Zealand white rabbit. Stem Cell Res Ther 4: 104.

Hiyama A, Mochida J, Iwashina T, Omi H, Watanabe T, Serigano K, Tamura F, Sakai D (2008) Transplantation of mesenchymal stem cells in a canine disc degeneration model. J Orthop Res 26: 589-600.

Hoogendoorn RJ, Lu ZF, Kroeze RJ, Bank RA, Wuisman PI, Helder MN (2008) Adipose stem cells for intervertebral disc regeneration: current status and concepts for the future. J Cell Mol Med 12: 2205-2216.

Iwashina T, Mochida J, Sakai D, Yamamoto Y, Miyazaki T, Ando K, Hotta T (2006) Feasibility of using a human nucleus pulposus cell line as a cell source in cell transplantation therapy for intervertebral disc degeneration. Spine 31: 1177-1186.

Ji JF, He BP, Dheen ST, Tay SS (2004) Interactions of chemokines and chemokine receptors mediate the migration of mesenchymal stem cells to the impaired site in the brain after hypoglossal nerve injury. Stem Cells 22: 415-427.

Kadereit S, Deeds LS, Haynesworth SE, Koc ON, Kozik MM, Szekely E, Daum-Woods K, Goetchius GW, Fu P, Welniak LA, Murphy WJ, Laughlin MJ (2002) Expansion of LTC-ICs and maintenance of p21 and BCL-2 expression in cord blood $\mathrm{CD} 34^{+} / \mathrm{CD} 38^{-}$early progenitors cultured over human MSCs as a feeder layer. Stem Cells 20: $573-582$.

Katz JN (2006) Lumbar disc disorders and low-back pain: socioeconomic factors and consequences. J Bone Joint Surg Am 88 Suppl 2: 21-24.

Kawada H, Fujita J, Kinjo K, Matsuzaki Y, Tsuma M, Miyatake H, Muguruma Y, Tsuboi K, Itabashi Y, Ikeda Y, Ogawa S, Okano H, Hotta T, Ando K, Fukuda K (2004) Nonhematopoietic mesenchymal stem cells can be mobilized and differentiate into cardiomyocytes after myocardial infarction. Blood 104: 3581-3587.
Kelsey JL, White AA 3rd (1980) Epidemiology and impact of low-back pain. Spine 5: 133-142.

Kitaori T, Ito H, Schwarz EM, Tsutsumi R, Yoshitomi H, Oishi S, Nakano M, Fujii N, Nagasawa T, Nakamura $\mathrm{T}$ (2009) Stem cell-derived factor 1/CXCR4 signaling is critical for the recruitment of mesenchymal stem cells to the fracture site during skeletal repair in a mouse model. Arthritis Rheum 60: 813-823.

Luoma K, Riihimäki H, Luukkonen R, Raininko R, Viikari-Juntura E, Lamminen A (2000) Low back pain in relation to lumbar disc degeneration. Spine 25: 487-492.

Mackenzie TC, Flake AW (2001) Human mesenchymal stem cells persist, demonstrate site-specific multipotential differentiation, and are present in sites of wound healing and tissue regeneration after transplantation into fetal sheep. Blood Cells Mol Dis 27: 601-604.

Masuda K, Imai Y, Okuma M, Muehleman C, Nakagawa K, Akeda K, Thonar E, Andersson G, An HS (2006) Osteogenic protein-1 injection into a degenerated disc induces the restoration of disc height and structural changes in the rabbit anular puncture model. Spine 31: 742-754.

Minges Wols HA, Underhill GH, Kansas GS, Witte PL (2002) The role of bone marrow-derived stem cells in the maintenance of plasma cell longevity. J Immunol 169: 4213-4221.

Miyamoto T, Muneta T, Tabuchi T, Matsumoto K, Saito H, Tsuji K, Sekiya I (2010) Intradiscal transplantation of synovial mesenchymal stem cells prevents intervertebral disc degeneration through suppression of matrix metalloproteinase-related genes in nucleus pulposus cells in rabbits. Arthritis Res Ther 12: R206.

Mizuguchi T, Palm K, Hui T, Aoki T, Mochizuki Y, Mitaka T, Demetriou AA, Rozga J (2002) Effects of bone marrow stem cells on the structural and functional polarity of primary rat hepatocytes. In Vitro Cell Dev Biol Anim 38: $62-65$.

Mochida J, Nishimura K, Nomura T, Toh E, Chiba M (1996) The importance of preserving disc structure in surgical approaches to lumbar disc herniation. Spine 21: 1556-1563.

Mochida J, Sakai D, Nakamura Y, Watanabe T, Yamamoto Y, Kato S (2015) Intervertebral disc repair with activated nucleus pulposus cell transplantation: a three-year, prospective clinical study of its safety. Eur Cells Mater 29: 202-212.

Nishida K, Suzuki T, Kakutani K, Yurube T, Maeno K, Kurosaka M, Doita M (2008) Gene therapy approach for disc degeneration and associated spinal disorders. Eur Spine J 17 Suppl 4: 459-466.

Nishimura K, Mochida J (1998) Percutaneous reinsertion of the nucleus pulposus. An experimental study. Spine 23: 1531-1538.

Nomura T, Mochida J, Okuma M, Nishimura K, Sakabe K (2001) Nucleus pulposus allograft retards intervertebral disc degeneration. Clin Orthop Relat Res 389: 94-101.

Okuma M, Mochida J, Nishimura K, Sakabe K, Seiki K (2000) Reinsertion of stimulated nucleus pulposus cells retards intervertebral disc degeneration: an in vitro and in vivo experimental study. J Orthop Res 18: 988-997. 
Orozco L, Soler R, Morera C, Alberca M, Sánchez A, García-Sancho J (2011) Intervertebral disc repair by autologous mesenchymal bone marrow cells: a pilot study. Transplantation 92: 822-828.

Pfirrmann CW, Metzdorf A, Zanetti M, Hodler J, Boos N (2001) Magnetic resonance classification of lumbar intervertebral disc degeneration. Spine 26: 1873-1878.

Riches PE, Dhillon N, Lotz J, Woods AW, McNally DS (2002) The internal mechanics of the intervertebral disc under cyclic loading. J Biomech 35: 1263-1271.

Sakai, D (2008) Future perspectives of cell-based therapy for intervertebral disc disease. Eur Spine J 17 Suppl 4: 452-458.

Sakai D, Mochida J, Yamamoto Y, Nomura T, Okuma M, Nishimura K, Nakai T, Ando K, Hotta T (2003) Transplantation of mesenchymal stem cells embedded in Atelocollagen ${ }^{\circledR}$ gel to the intervertebral disc: a potential therapeutic model for disc degeneration. Biomaterials 24: 3531-3541.

Sakai D, Mochida J, Iwashina T, Watanabe T, Nakai T, Ando K, Hotta T (2005) Differentiation of mesenchymal stem cells transplanted to a rabbit degenerative disc model: potential and limitations for stem cell therapy in disc regeneration. Spine 30: 2379-2387.

Sakai D, Mochida J, Iwashina T, Hiyama A, Omi H, Imai M, Nakai T, Ando K, Hotta T (2006) Regenerative effects of transplanting mesenchymal stem cells embedded in atelocollagen to the degenerated intervertebral disc. Biomaterials 27: 335-345.

Sakai D, Nakamura Y, Nakai T, Mishima T, Kato S, Grad S, Alini M, Risbud MV, Chan D, Cheah KS, Yamamura K, Masuda K, Okano H, Ando K, Mochida J (2012) Exhaustion of nucleus pulposus progenitor cells with ageing and degeneration of the intervertebral disc. Nat Commun 3: 1264.

Sakai D, Nishimura K, Tanaka M, Nakajima D, Grad S, Alini M, Kawada H, Ando K, Mochida J (2014) Migration of bone marrow-derived cells for endogenous repair in a new tail-looping disc degeneration model in the mouse: a pilot study. Spine J 15: 1356-1365.

Sardonini CA, Wu YJ (1993) Expansion and differentiation of human hematopoietic cells from static cultures through small-scale bioreactors. Biotechnol Prog 9: 131-137.

Serigano K, Sakai D, Hiyama A, Tamura F, Tanaka M, Mochida J (2010) Effect of cell number on mesenchymal stem cell transplantation in a canine disc degeneration model. J Orthop Res 28: 1267-1275.

Tanaka M, Sakai D, Hiyama A, Arai F, Nakajima D, Nukaga T, Nakai T, Mochida J (2013) Effect of cryopreservation on canine and human activated nucleus pulposus cells: a feasibility study for cell therapy of the intervertebral disc. Biores Open Access 2: 273-282.

Vadalà G, Sowa G, Hubert M, Gilbertson LG, Denaro V, Kang JD (2012) Mesenchymal stem cells injection in degenerated intervertebral disc: cell leakage may induce osteophyte formation. J Tissue Eng Regen Med 6: 348-355.

Wang L, Li Y, Chen X, Chen J, Gautam SC, Xu Y, Chopp M (2002) MCP-1, MIP-1, IL-8 and ischemic cerebral tissue enhance human bone marrow stem cell migration in interface culture. Hematology 7: 113-117.
Watanabe T, Sakai D, Yamamoto Y, Iwashina T, Serigano K, Tamura F, Mochida J (2010) Human nucleus pulposus cells significantly enhanced biological properties in a coculture system with direct cell-to-cell contact with autologous mesenchymal stem cells. J Orthop Res 28: 623-630.

Yamamoto Y, Mochida J, Sakai D, Nakai T, Nishimura K, Kawada H, Hotta T (2004) Upregulation of the viability of nucleus pulposus cells by bone marrow-derived stromal cells. Spine 29: 1508-1514.

Yoshikawa T, Ueda Y, Miyazaki K, Koizumi M, Takakura Y (2010) Disc regeneration therapy using marrow mesenchymal cell transplantation: a report of two case studies. Spine 35: E475-E480.

\section{Discussion with Reviewers}

Reviewer I: The authors propose cryopreservation of NP cells (and BMSCs) of patients undergoing herniotomy or spinal fusion, so that these cells could be reintroduced at a later time point. However, NP cells from a degenerative human disc are expected to be less active than NP cells from healthy canine discs. Which quality tests will be required to ensure the efficacy of cryopreserved cells after thawing and before transplantation?

Authors: As you mention, we are aware that NP cells from surgical patients may be less active. That is why we came up with the coculture method. In our previous human study, cell proliferation and viability after coculture were used as parameters for quality control. In an experiment with humans, we attempted to activate NP cells using a direct cell-to-cell type coculture system in which human autologous MSCs could adhere to dendrites by means of a $0.4 \mu \mathrm{m}$-pore size membrane. Compared with the cell group cultured in a normal monolayer, in the cell group cocultured with direct cell-to-cell contact we identified an increase in cell proliferation, DNA synthesis, and proteoglycan synthesis by 2.3-, 5.2- and 5.7-fold, respectively. These data demonstrated that the coculture system of direct cell-to-cell contact with BMSCs enhances cellular activity, which may extend to degenerated human specimens that require surgery (Watanabe et al., 2010). The patients that do not meet the quality would not be recruited. We believe that this format can also be applied to cryopreserved cell transplantations.

Reviewer II: Can the similar outcome observed in the $\mathrm{N}$ and $\mathrm{F}$ groups be solely explained by the nil effects of cryopreservation? Could the extent of cell engraftment have an influence, which has not been assessed in this work?

Authors: From the current data, it seems that the result of a non-significant difference between the $\mathrm{N}$ and $\mathrm{F}$ groups is not due to the extent of cell engraftment. In order to justify this, we have included data to show percentage of GFPpositive cells after transplantation (Fig. 11).

Editor's Note: Scientific Editor in charge of the paper: Brian Johnstone. 